DHAXNA SOTHIESON

\title{
DOTCOM'S MEGA MESS: \\ NEW ZEALAND'S ROLE IN A FOREIGN SEARCH WARRANT REQUEST
}

Submitted for the LLB (Honours) Degree

Faculty of Law

Victoria University of Wellington

2013 
In January 2012, the United States requested the assistance of the New Zealand government under the Mutual Assistance in Criminal Matters Act 1992 (MACMA) to execute a search warrant at Kim Dotcom's residence. A few months later, the High Court held that this warrant was invalid and its execution unlawful. The case illustrates the importance of effective cooperation between two executive authorities. This article will build on the case and argue that the flexibility of MACMA provisions must be used by domestic authorities to ensure that a request accords with domestic law and fulfils the purpose of the Act. The flexibility of these provisions are even more important to utilise under the new landscape of the Search and Surveillance Act 2012, enacted after Dotcom v Attorney-General, to ensure that New Zealand can register and enforce a foreign search warrant request.

[Mutual Assistance in Criminal Matters Act 1992, international criminal cooperation, Search and Surveillance Act 2012, search warrant.] 


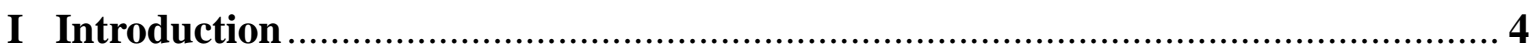

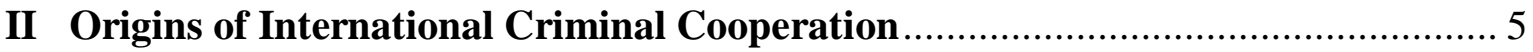

A Response from Commonwealth Countries and United Nations ............................ 5

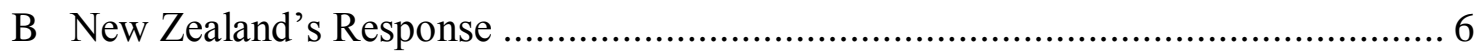

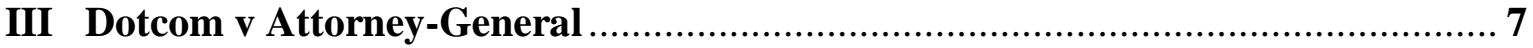

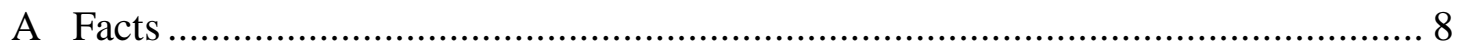

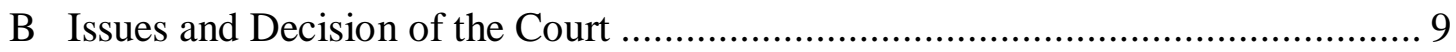

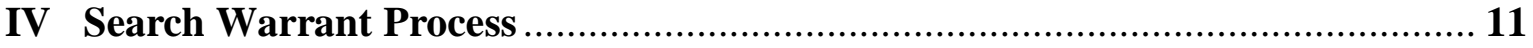

A Overview of the Role of the Requesting and Requested Country ...................... 12

B Permissible Enforcement Action: The Attorney-General's Role in Receiving a

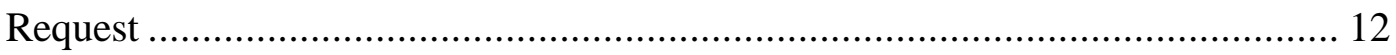

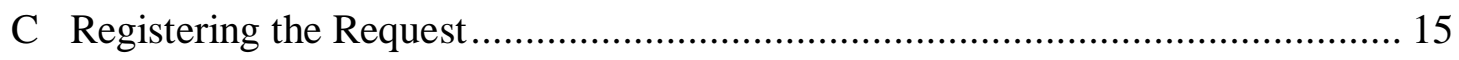

D Ascertaining Relevancy during Execution ................................................... 17

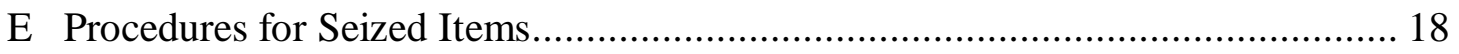

F Forensic Copies and Mixed Content Devices .................................................... 20

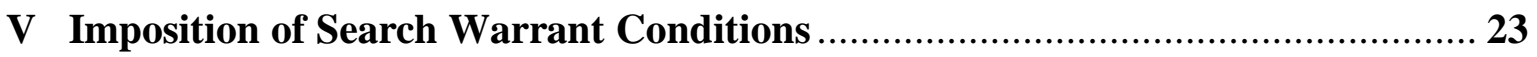

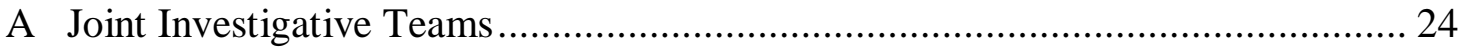

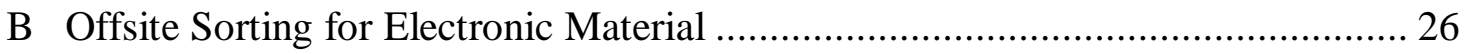

C Retention of Mixed Content Devices ........................................................... 28

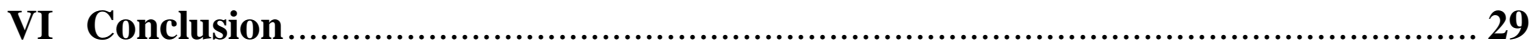

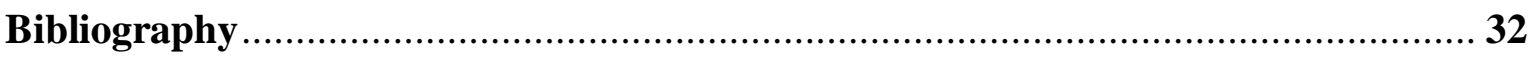




\section{Introduction}

Dotcom v Attorney-General ${ }^{1}$ illustrates the difficulty New Zealand, as a requested country, faces when registering and giving effect to a foreign search warrant request. The United States was able to request this assistance under the Mutual Assistance in Criminal Matters Act 1992 (MACMA). MACMA was enacted to show that New Zealand "is prepared to play its part in the fight against international crime". ${ }^{2}$ The Act provides a statutory framework for formal cooperation between the New Zealand government and a requesting country.

The question following Dotcom v Attorney-General is New Zealand's proper role, as a requested country, upon receiving a search warrant request. This article argues that New Zealand authorities must use the flexibility of the statutory provisions in MACMA to ensure that a request can be carried out in accordance with domestic law. At each stage of the search warrant process, MACMA provisions can ensure that enforcement action is permissible, relevance of things to be seized can be ascertained, and procedures for dealing with seized items and forensic copies are consistent with domestic law and the purpose of MACMA. This enables authorities to be responsive to developments in crime and technology that can lead to legislative gaps.

The article begins by providing an overview of the developments in international criminal cooperation and New Zealand's response in Section II. Section III discusses the facts and issues Dotcom v Attorney-General raise concerning the role of the requested country. Section IV looks at the search warrant process, and the difficulties New Zealand authorities have in ensuring that the request can be given effect, especially facing the new legislative landscape under the Search and Surveillance Act 2012. Lastly, Section V suggests that the imposition of search warrant conditions can overcome the difficulties identified in Section IV. These conditions can providing clarity and ensure that the request is compatible with domestic law and the purpose of MACMA.

\footnotetext{
Dotcom v Attorney-General [2012] NZHC 1494, [2012] 3 NZLR 115. [Dotcom].

(20 August 1992) 528 NZPD 10827.
} 


\section{Origins of International Criminal Cooperation}

Prior to the $1980 \mathrm{~s}$, crime was regarded a local matter and states were not concerned with assisting other states in using their enforcement jurisdiction. ${ }^{3}$ Aside from extradition, assistance was limited to forms of informal cooperation such as cooperation between national police forces through Interpol. Unlike the criminal jurisdiction, cooperation was common in civil and commercial matters where measures for the service of process and taking of evidence abroad had existed for a long time. ${ }^{4}$

With developments in technology and patterns of organised crime enhancing transnational crime, criminals were able to take advantage of the lack of international cooperation and move themselves, as well as the instruments and proceeds of crime between countries to evade authorities. ${ }^{5}$ Particular crimes causing concern were drug and human trafficking, commercial fraud and money laundering. ${ }^{6}$ Crime could no longer be regarded a local matter. The law needed to respond to these crimes regarded as injurious to the international community as a whole.

\section{A Response from Commonwealth Countries and United Nations}

In response, the Harare Scheme and the United Nations Model Treaty were formulated to provide a framework for states to develop the provision of assistance. Although it is not possible to directly apply foreign law in foreign countries, the basis of cooperation is that existing measures of compulsion in one country should be made available to the prosecuting authorities of another country. ${ }^{7}$ A request by a foreign country (requesting country) is registered in the requested country and takes effect as if it were a domestic

3 Clive Nicholls, Clare Montgomery and Julian B. Knowles The Law of Extradition and Mutual Assistance (2nd ed, Oxford University Press, Oxford, 2007) at [17.04].

4 David McClean International Co-Operation in Civil and Criminal Matters (3rd ed, Oxford University Press, Oxford, 2012, at 27 and 73.

5 Nicholls, Montgomery and Knowles, above n 3, at [17.01].

6 McClean, above $\mathrm{n} 4$, at 154 . Terrorism can now be added to the list of particular crimes.

7 Scheme Relating to Mutual Assistance in Criminal Matters within the Commonwealth: Explanatory Material prepared for Commonwealth Jurisdictions (Commonwealth Secretariat, London, 1988) at Preface. ["Explanatory Material prepared for Commonwealth Jurisdictions"]. 
action. The requested country's laws govern the execution of the request without interference from the requesting country, thereby removing any purported extra-territorial effect of the request that had made assistance objectionable in the past.

The Commonwealth Scheme, known as the Harare Scheme, was concluded in $1986 .{ }^{8}$ Similar requirements from the Commonwealth's extradition scheme were used, including the threshold for a relevant offence to request assistance; dual criminality in the requesting and requested country; and a political offences exception to refuse assistance. ${ }^{9}$ The Scheme provides a broad platform for a guaranteed level of cooperation Commonwealthwide, and one which can be enhanced on a bilateral basis. ${ }^{10}$ A prescribed form of request was decided to be incompatible with the diverse fact situations that required assistance, allowing requests to adapt to changing circumstances. ${ }^{11}$ The Scheme leaves individual governments to decide what measures shall be available to a requesting country. ${ }^{12}$

Following the Harare Scheme, in 1990 the United Nations adopted the text of a model treaty to be used as a basis for future negotiations between Member States. ${ }^{13}$ This Model Treaty on Mutual Assistance in Criminal Matters provides a "useful framework that could be of assistance to States interested in negotiating and concluding bilateral agreements aimed at improving co-operation in matters of crime prevention". ${ }^{14}$ The Harare Scheme and Model Treaty are revised periodically to address areas of uncertainty and/or concerns of states, as well as to reflect changes in technology and types of assistance.

\section{B New Zealand's Response}

MACMA was enacted in response to both the Harare Scheme and United Nations Model Treaty. ${ }^{15}$ Following from these, it provides assistance in two areas:

\footnotetext{
Scheme Relating to Mutual Assistance in Criminal Matters within the Commonwealth (Harare Scheme). Note that dual criminality is now a discretionary ground for refusal under s 27(2)(a).

Explanatory Material prepared for Commonwealth Jurisdictions, above n 7, at Preface.

11 McClean, above n 4, at 180.

12 Explanatory Material prepared for Commonwealth Jurisdictions, above n 7, Introductory paper at [18].

13 McClean, above $\mathrm{n}$ 4, at 185.

14 Model Treaty on Mutual Assistance in Criminal Matters GA Res 45/117, A/RES/45/117 (1990).

15 Solicitor-General v Bujak [2008] NZCA 334, [2009] 1 NZLR 185 at [23]. [Solicitor-General v Bujak].
} 
1. International judicial assistance in locating witnesses, service of process, production of evidence, and search and seizure requests.

2. Tracing, seizure and forfeiture of the instruments and proceeds of crime.

All requests are made to or from the Attorney-General, as the designated "Central Authority". ${ }^{16}$ MACMA allows New Zealand to accept requests from a prescribed foreign country or any convention country. ${ }^{17}$ It was recognised during its Bill stage that New Zealand could provide assistance to non-Commonwealth countries on a bilateral basis or ad hoc basis based on reciprocity. ${ }^{18}$ The United States of America became a prescribed foreign country in $1998 .{ }^{19}$ This was how they were able to request New Zealand's assistance in Dotcom.

\section{Dotcom v Attorney-General}

The raid on internet mogul Kim Dotcom's mansion on 20 January 2012 culminated in multiple legal battles played out in New Zealand courts. ${ }^{20}$ The search warrants were issued under ss 43 and 44 of MACMA, propelling this legislation into the spotlight. Litigation split into issues with the GCSB illegal spying, and an extradition case with the latest Supreme Court hearing on July 2013 regarding the disclosure of evidence. ${ }^{21}$ Litigation under MACMA has focused on the lawfulness of the search warrant and execution, and custody and procedures for the seized items. ${ }^{22}$

16 MACMA, s 2(1). "Means the person or authority for the time being designated by that country for the purposes of transmitting or receiving requests made under or pursuant to this Act".

17 Ibid. Prescribed foreign country means any country that is declared by regulations to be a foreign country to which Part 3 of MACMA applies. Current prescribed countries are Australia, Fiji, Hong Kong, Niue, China, The Republic of Korea, the United Kingdom and the United States of America.

A convention country means any foreign country that is a party to a convention referred to in column 1 of the table in Schedule 1.

18 (20 August 1992) 528 NZPD 10826. Now contained in MACMA, s 25(A)(2).

19 Mutual Assistance in Criminal Matters (Prescribed Foreign Country) (United States of America) Regulations 1998, reg 1.

20 There have been 16 reported cases to date.

21 David Fisher "Dotcom lawyers argue to see evidence" The New Zealand Herald (online ed, Auckland, 30 July 2013). At the time of writing this article the Supreme Court has yet to issue a judgment regarding disclosure of evidence. The extradition hearing is expected now to occur in April 2014. 
The United States, on behalf of the Federal Bureau of Investigation (FBI), requested the search and seizure of items at Dotcom's property in conjunction with the Megaupload companies. $^{23}$ Dotcom was being investigated by the FBI for breach of criminal copyright, conspiracy to breach criminal copyright, conspiracy to commit money laundering, and conspiracy to commit racketeering. ${ }^{24}$ The Megaupload websites and associated companies administered by Dotcom were said to be used by third parties to reproduce and distribute copyrighted material such as motion pictures, and to conduct monetary transactions with the proceeds of these unlawful activities. ${ }^{25}$

The North Shore District Court granted the search warrant on 19 January 2012. To preserve its evidential integrity, Police protocol dictated the removal of computer hard drives offsite for forensic examination. ${ }^{26}$ Around 150 terabytes of data were removed in executing the search warrant. ${ }^{27}$ However, these items were not checked for relevance to the offence. Forensic copies (referring to the replication of computer data) were made of some computer hard drives. All of the seized items were to be kept under the custody of the Commissioner of Police pursuant to the Attorney-General's direction on 16 February 2012 under s 49(3) of MACMA. However, some of the forensic copies were sent to the FBI after this direction.

Procedures for dealing with the seized items were not addressed in the memorandum filed in support of the application by the police. ${ }^{28}$ The key problem was that the police had and have had no request from the United States to sort through the broad category of items

22 Assets were restrained under s 60 of MACMA. The arrest and extradition of Dotcom was also requested, a separate issue not covered under MACMA. A "remedies hearing" for public law damages has been postponed for procedural reasons after Winkelmann $\mathrm{J}$ said Police conduct could amount to unreasonable search and seizure under s 21 of the New Zealand Bill of Rights Act 1990.

23 There are four named plaintiffs, the three others are associates of Dotcom's; Finn Bato, Mathias Ortman and Bram Van der Kolk. For brevity they will be referred to as Dotcom. Assets of all four plaintiffs were seized. A second warrant was also executed at Van Der Kolk's property.

24 Dotcom, above n 1, at [10].

25 At [11].

26 At [21].

27 At [25].

28 At [16]. 
seized for relevance. The question New Zealand authorities should have asked was whether the FBI could have full custody and control over the items to carry out this task themselves.

\section{$B$ Issues and Decision of the Court}

Winkelmann $\mathbf{J}$ addressed three main issues in the High Court on 28 June 2012. The subsequent judgment on 31 May 2013 added further processes to the earlier orders, but largely repeated the earlier decision. The issues discussed below provide the basis for discussion in Section V and VI.

\section{Was the search warrant invalid?}

The offences were not adequately described in the warrant making them general warrants. The warrant listed the offences as "breach of copy right and money laundering" without stating what country's laws these offences contravened. ${ }^{29}$ Copyright can exist in many things and may be breached in many ways, no description was provided about what the offences were in relation to. ${ }^{30}$

The consequence of this was that warrants authorised the search and seizure of a wide variety and amount of items. Appendix A listed items such as: ${ }^{31}$

...all digital devices, including electronic devices capable of storing and/or processing data in digital form, including, but not limited to...central processing units...desktop, laptop, or notebook computers....mobile telephones.

The inevitability of capturing irrelevant material was compounded by the execution of the search warrant at Dotcom's personal residence. Winkelmann $J$ held that the issuing judge could not have been satisfied there were reasonable grounds for suspecting that all

29 At [18] and [40].

30 At [41] and [46].

31 At [19]. 
of the things listed in Appendix A were evidence of breach of copyright or money laundering. ${ }^{32}$

2 Did the Police execution exceed the scope of the search warrant?

Winkelmann $\mathrm{J}$ went on to consider that even if the warrants were valid, police execution exceeded lawful authority as irrelevant material continued to be held unlawfully. ${ }^{33}$ The warrant application did not provide information on when, where or by whom the sorting exercise was to take place. ${ }^{34}$ The police argued it was for the FBI to undertake this exercise in the interests of cost and time because the New Zealand police lacked specialist equipment.

The judge held that the items could be removed offsite if the police reasonably believed they contained material of evidential value. However, "issues of relevance must be determined at the time of the search and offsite sorting process". ${ }^{35}$ Retention of computer hard drives could be justified because they were devices on which the offences had been committed, but not the irrelevant digital information on it. ${ }^{36}$

\section{Was the sending of forensic copies to the FBI unlawful?}

The Attorney-General gave a direction on 16 February 2012 under s 49(2) that seized items were to remain in the custody and control of the Commissioner of Police. However, some forensic copies of hard drives were shipped to the FBI contrary to this. This was held to be in breach of s 43(3), and the court ordered the voluntary return of these copies from the FBI.

\section{Court Orders}

\footnotetext{
At [56].

At [88].

4 At [88].

35 At [76].

36 At [62].
} 
Procedures for the seized items were addressed in the second judgment. Items containing wholly irrelevant material were to be returned to Dotcom. Two different clones were to be created for items identified as mixed content devices (those containing both relevant and irrelevant material). One "complete" clone provided to Dotcom, and one "disclosable" clone with any personal photographs or film deleted to the United States. ${ }^{37} \mathrm{~A}$ copy was also ordered to be provided to Dotcom, prior to its sending offshore, where the item contains only relevant material. Winkelmann $\mathrm{J}$ held this process should be done at the expense of the police.

Though Dotcom can be treated as an exceptional case, due to its large-scale nature, important lessons can be learned for registering and enforcing future search warrants, given the increasing number of MACMA requests received by New Zealand. ${ }^{38}$

\section{Search Warrant Process}

A search warrant is judicial authority, granted ex parte, allowing for a substantial invasion of the privacy and property rights of the individual concerned. ${ }^{39}$ The Search and Surveillance Act aims to modernise existing statutes for search, seizure and surveillance. It now governs domestic search warrants and parts of a foreign request, changing the landscape for future MACMA requests as the Act has taken effect following Dotcom. The interaction between these two statutes leaves some areas of a request uncertain under domestic law. Furthermore, there are also uncertainties caused by the nature of a foreign request. The lack of operational knowledge can result in difficulties for domestic authorities to determine the required level of specificity for the warrant and ensuring its execution is in line with domestic law.

37 Dotcom v Attorney-General [2013] NZHC 1269 at [65]. [Second Dotcom judgment].

38 Statistics from Crown Law Office and Report of the Informal Expert Working Group on Mutual Legal Assistance Casework Best Practice (United Nations Office on Drugs and Crime, Vienna) 3-7 December 2001. In 2012, 42 requests were received by New Zealand; in 201138 received; in 201044 received; in 200931 requests received; in 200820 received; and in 200717 received.

39 Law Commission Search and Surveillance Powers (NZLC R97, 2007) at [2.11] and [4.71]. [Search and Surveillance Powers]. 


\section{A Overview of the Role of the Requesting and Requested Country}

A request is initially an exercise between two executive authorities with minimal judicial interference. The requesting country sets out its grounds for why it believes the thing is in New Zealand and why it is relevant to the investigation or court proceeding (criminal matter). ${ }^{40}$ The basis of the request cannot be challenged in the requested country. ${ }^{41}$ Probable time constraints mean that the more detailed the provision of information from the requesting country, the faster the request can be undertaken.

Dotcom has shown that although the requesting country is primarily responsible for ensuring the request can be undertaken, the onus is ultimately on the requested country to ensure that the request can be carried out in accordance with its domestic law. The requested country must be sure that the request asks for permissible enforcement action as the consequences of unlawful domestic action results in slowing down the investigation/proceeding in the requesting country.

\section{B Permissible Enforcement Action: The Attorney-General's Role in Receiving a Request}

The Attorney-General plays an important role as the designated Central Authority under MACMA. ${ }^{42}$ The Attorney-General must balance two objectives: respecting the wishes of the requesting country in the interests of cooperation whilst not granting more than permissible under domestic law. In A (A Firm of Solicitors) v Auckland District Court, Wild J said the "Attorney-General's role can be viewed as a screening or checking process". ${ }^{43}$ The case held that the New Zealand Detective in charge of requesting a search

40 Crown Law Office "Assistance for Foreign Authorities: Central Authorities" <www.crownlaw.govt.nz/pagepub/docs/afa/centralauthorities.asp\#7>

41 Government of the United States of America v Montgomery (No 2) [2004] UKHL 37, [2004] 1 WLR 2241. Unless the individual has suffered or risks suffering a flagrant denial of justice in the requesting country.

42 Crown Law Office, above n 40. In practice, “the Attorney-General's powers under MACMA are largely delegated to the Solicitor-General, who is an appointed Law Officer. Lawyers at Crown Law Office, the Office of the Solicitor-General, therefore undertake the legal work required to make or fulfil mutual assistance requests".

43 A (A Firm of Solicitors) v District Court at Auckland [2012] NZCA 246, [2012] 2 NZLR 844 at [42]. 
warrant was entitled to place reliance on the Attorney-General's authorisation of the application. $^{44}$

\section{Right of Refusal}

The Attorney-General carries the power to refuse a request. Mandatory grounds of refusal are contained in MACMA s 27(1) and discretionary grounds in s 27(2).

\section{Refusal of assistance}

(1) A request by a foreign country for assistance under this Part shall be refused if, in the opinion of the Attorney-General,-

(h) the request is for assistance of a kind that cannot be given under this Act, or would require steps to be taken for its implementation that could not lawfully be taken.

$\mathrm{S} 27(1)(\mathrm{h})$ is an important provision and is based on the Harare Scheme to ensure that the requested country is not required to do more that it would do in a purely domestic case. ${ }^{45}$ For example, if the taking of body samples is not provided for under the relevant law of the requested country it can refuse the request. ${ }^{46}$

\section{(a) Removing unlawful steps}

The second part of $s$ 27(1)(h) raises an important issue about a request containing unlawful steps for implementation in the requested country. These steps may arise during the course of cooperation, before or after the request has been made, where the requesting country asks or changes its requested enforcement action. Although it is a mandatory ground of refusal, s 27(1) gives latitude to the opinion of the Attorney-General. To refuse a request where cooperation could remove the unlawful step would contravene the purpose of the legislation to provide assistance where possible. S 27(1)(h) should be a last resort where reading down the request in line with domestic law is not possible.

Ibid.

45 McClean, above n 4, at 182.

46 Explanatory Material prepared for Commonwealth Jurisdictions, above n 7, Commentary at 27. The availability of these procedures under other domestic legislation is immaterial. 
In Bujak v Solicitor-General, Poland requested New Zealand register and enforce a foreign restraining order (FRO) against a Polish resident in New Zealand. ${ }^{47}$ The FRO purported to do more than restrain the property of Mr Bujak, it purported to "seize" assets in some plain language used in the request, which would be impermissible under domestic law. ${ }^{48}$ A FRO is meant to freeze assets pending a court determination to forfeit/confiscate these assets. ${ }^{49}$ The Court of Appeal and Supreme Court held that this was not the intention of the request, as the Polish Order as a whole was directed to restraint rather than seizure. ${ }^{50}$ The Court of Appeal held that even if the Polish Order was to go further than restraining Mr Bujak's property, it nonetheless may be registered and have effect within the narrower scope permissible under New Zealand law. ${ }^{51} \mathrm{~S} 57(3)$ of MACMA stated that when an order is registered it takes effect as if it were a restraining order made under the Proceeds of Crimes Act $1991 .^{52}$ Therefore, any purportedly wider operation of the foreign order than is permissible under domestic law is stripped away.

This article would add one qualifier to the Court of Appeal's decision. If a request is wider than permissible under domestic law, this should be brought to the attention of the requesting country as soon as possible. ${ }^{53}$ Removing the unlawful step should not be done unilaterally by the requested country as this would undermine the purpose of cooperation and the intention of the requesting country. Although this may be a barrier to expediency, better cooperation can result in a request where both authorities are clear on its execution.

For example, in the $A$ (A Firm of Solicitors) case, the Attorney-General questioned part of the request to search A's personal residence. The other part of the request was to search A's business). There were emails between the two authorities, and the court drew the inference that the Attorney-General queried the propriety of or necessity for the search at A's personal residence. ${ }^{54}$ As a result, the United Kingdom Serious Fraud Office withdrew

\footnotetext{
47 Bujak v Solicitor-General [2009] NZSC 42, [2009] 3 NZLR 179 at [4]. [Bujak v Solicitor-General].

48 At [6].

49 At [12].

50 At [21] and [23].

51 Solicitor-General v Bujak, above n 15, at [27] and [41].

52 At [27]. Now replaced by the Criminal Proceeds (Recovery) Act 2009.

53 See also the Harare Scheme, art 7(3).
} 
this part of the request, rather than the New Zealand authorities omitting this part of the search from the warrant application.

\section{(b) How would this have applied to Dotcom?}

It was clear in Bujak that the intention of the Polish authorities was never to do anything more than restrain property. In Dotcom the FBI wanted all the material seized to ascertain relevance themselves; an impermissible step under New Zealand law. To narrow the scope of the request would not have been possible without cooperation and would go against the intention of the requesting country. If cooperation could not remove the unlawful step, the Attorney-General should have refused the request. The AttorneyGeneral plays an important role at first instance, and can interpret s 27(1)(h) in light of the broader purpose of MACMA to facilitate cooperation, where possible, towards domestic compliance.

\section{Registering the Request}

If the request is approved under s 43 of MACMA, the Attorney-General can authorise a constable to apply to an issuing officer (judge) for a search warrant under s 44 . If the application is made consistently with the provisions of subpart 3 of Part 4 of the Search and Surveillance Act, the judge may grant the warrant.

\section{Search warrants}

(1) An issuing officer who, on an application made in the manner provided in subpart 3 of Part 4 of the Search and Surveillance Act 2012, is satisfied that there are reasonable grounds for believing that there is in or on any place or thing-

(a) any thing upon or in respect of which any offence under the law of a foreign country punishable by imprisonment for a term of 2 years or more has been, or is suspected of having been, committed; or

(b) any thing which there are reasonable grounds for believing will be evidence as to the commission of any such offence; or

\footnotetext{
54 A (A Firm of Solicitors) v District Court at Auckland, above n 43, at [13].
} 
(c) any thing which there are reasonable grounds for believing is intended to be used for the purpose of committing any such offence-

may issue a search warrant in respect of that thing.

(2) An application for a warrant under subsection (1) may be made only by a constable authorised under section 43(2).

(3) The provisions of Part 4 of the Search and Surveillance Act 2012 (except subpart 6) apply.

S 44 is an important provision as it sets out the relationship between MACMA and the Search and Surveillance Act. The constable and judge are responsible for implementing the request in accordance with domestic law. The court is not simply a rubber stamp and also plays an important role to check the request is in accordance with domestic law. ${ }^{55}$ As a judge "may" issue a warrant, s 44(1) implies that he or she can refuse/modify a search warrant application. In line with the spirit of MACMA the judge must try give effect to a request over refusing to register it. An illustration of the discretionary power an issuing officer has is in Solicitor-General v Beneficial Owners of Various Bank Accounts. Ronald Young J sent the FRO request back to the New South Wales (NSW) authorities, as once registered it would entitle the Public Trustee of NSW to effectively uplift funds from the New Zealand bank accounts and transfer them to Australia. Ronald Young J said "this power seemed to me to be more than a restraining order with respect to the funds" ${ }^{56}$ New Zealand then obtained an amended order from the NSW authorities addressing this mischief. Issuing officers should be alert to these possibilities, as analogous to the Attorney-General, they too can remove unlawful steps to ensure the request accords with domestic law.

\section{Importance of specificity}

The level of specificity required in each search warrant is fact-specific. Specificity is an important protection for the individual against the improper use of an intrusive state power. ${ }^{57}$ New Zealand authorities have tended to replicate information provided by the

55 JP Morgan Chase Bank National Association v Director of the Serious Fraud Department [2012] EWHC 1674 (Admin) at [53].

56 Solicitor-General v Beneficial Owners of Various Bank Accounts CIV-2008-485-1070, 21 May 2008 at [2]. 
requesting country when registering the request. ${ }^{58}$ Although this is consistent with mutual reliance, it can cause problems where the required level of specificity is not met.

S 103(4)(g) of the Search and Surveillance Act states that the warrant must have a "description of what may be seized". To overcome the difficulty that electronic material posed in Dotcom, the warrant should state that all computer hard drives the offence is believed to have been committed on will be searched for relevant material. There may be cases where the wide ranging nature of the offence makes it difficult to frame the application for a warrant in very specific terms. ${ }^{59}$ Factors such as the stage of the criminal matter should also be considered, as a wider category of items may be requested at an early investigative stage. Likely time constraints and the breadth of supporting documents for the warrant can also leave room for error. The issuing officer has the final authorisation to decide what is possible to specify in the particular circumstances. ${ }^{60}$ This role is largely identical to considerations for purely domestic requests. The judge must not be afraid to request further information from the requesting country even if it risks slowing down the process.

\section{$D$ Ascertaining Relevancy during Execution}

The police must ensure that in executing the warrant they exercise powers in accordance to the Search and Surveillance Act and s 21 of the New Zealand Bill of Rights Act 1990 which protects an individual against unreasonable search and seizure. A search warrant cannot authorise seizure of irrelevant material. ${ }^{61}$ If evidence is obtained unlawfully in New Zealand, the individual can challenge its admissibility in the requesting country in accordance with an equivalent s 36 MACMA provision.

There must to be a link between the item seized and the criminal matter, and this must be considered again at execution. The detail of this link, alike to specificity, is fact-based.

57 Search and Surveillance Powers, above n 39, [4.135]-[4.136].

58 Dotcom, above n 1, at [16]; A v District Court at Auckland CIV-2011-404-4796 22 December 2011 at [24]. [Av District Court at Auckland].

59 A v District Court at Auckland, above n 58, at [95].

60 Ibid.

61 Dotcom, above n 1, at [77]. 
Executing a search warrant still requires that items be checked for relevance to the offence, even if they are specified clearly in the warrant. Relevancy can be determined on site or offsite. ${ }^{62}$ This safeguard is to prevent what is known in the civil jurisdiction as a "fishing expedition" and ensure that irrelevant material is protected. ${ }^{63}$ Ascertaining relevance requires knowledge of the criminal matter and may be the most time intensive part of the process, especially if there is a broad category of items to be searched.

The requested country must be clear on how and by whom relevance can be ascertained. It presumes a high level of information and cooperation between the authorities about the scope of items to be searched and seized. The difficulty of this process was exacerbated in Dotcom due to the scale of items to be searched. However, in a previous case of $A$ (A Firm of Solicitors) the items were of a narrower scope and detailed information was provided about the investigation. Operational knowledge will always be a barrier and cooperation is vital for relevance to be determined. Section V will look at ways in which this process can be better managed.

\section{E Procedures for Seized Items}

The procedures to deal with seized items under domestic law are set out in Part 4, subpart 6 of the Search and Surveillance Act. However, this provision is excluded under MACMA s 44(3). If a computer hard drive only constitutes a thing seized under the Search and Surveillance Act, the question is what procedures apply to the electronic material under MACMA.

\section{Why is subpart 6 excluded from MACMA?}

The reason behind the amendment to s 44(3) of MACMA on 1 October 2012 is not on public record. ${ }^{64}$ It was inserted in s 335, Part 5 of the Search and Surveillance Act enacted

62 Search and Surveillance Act 2012, s 112 legitimises the offsite sorting process by allowing items of uncertain status to be removed from the site to determine whether it may lawfully be seized.

63 Lord Collins et al (eds) Dicey, Morris \& Collins on the Conflict of Laws $\left(15^{\text {th }}\right.$ ed, Sweet \& Maxwell, London, 2012) at 8-103. 
to amend and repeal other domestic legislation. This article puts forward two reasons for this amendment.

Firstly, the exclusion assumes cooperation between the authorities as to whether the items seized are to be sent to the requesting country. The procedures in the Search and Surveillance Act contemplate local trial and use of the seized materials under domestic law. Under MACMA seized items are likely to be sent overseas, and the requesting country gains custody of them. ${ }^{65}$

Secondly, under s 49(2) the decision for the sending of seized material lies with the Attorney-General which provides that-

\begin{abstract}
49(2)
Where a thing is delivered into the custody of the Commissioner of Police under subsection (1), the Commissioner of Police shall arrange for the thing to be kept for a period not exceeding 1 month from the day on which the thing was seized pending a direction in writing from the Attorney-General as to the manner in which the thing is to be dealt with (which may include a direction that the thing be sent to an appropriate authority of a foreign country).
\end{abstract}

If no direction is given by the Attorney-General before the end of one month, under s 49(4) the Commissioner of Police has to return the things to the individual as soon as practicable. S 156 of the Search and Surveillance Act that manages the application for release/access to things seized does not apply (as it is in subpart 6) because by then Attorney-General has at its power the ability to deal with that material. There are no equivalent provisions in MACMA.

The procedures governing seized items are all left to the direction of the AttorneyGeneral. The main concern is that this emphasis on cooperation creates too much

64 Ministry of Justice official correspondence stated "the rules in subpart 6 of Part 4 of the Search and Surveillance Act are not applicable to MACMA because the specific provisions in MACMA are required to allow that regime to work". Searches of Parliamentary Debates, Select Committee Reports did not provide any further information.

65 In MACMA, there is no provision that once these items are no longer needed they are to be returned to the requested country. But see the Harare Scheme art 23(2) and UN Model Treaty. 
flexibility leading to uncertainty for the executing authorities and individual. As items remain in police custody, police must ensure they follow the s 49 direction. The requested country must always be alert to this possibility of sending material overseas and have processes in place to ensure that when items are sent, the s 49 direction is followed and any conditions imposed on the seized items.

\section{F Forensic Copies and Mixed Content Devices}

\section{Position under domestic law}

Under s 3 of the Search and Surveillance Act a forensic copy of a computer hard drive does not constitute "things seized". Rather it is the hard drive that constitutes a "thing" to be searched and seized. Under this interpretation section of the Act, a seized item does not include anything made or generated by a person exercising a search and surveillance power. This would also be likely to apply to copies of tangible documents. These copies are therefore not subject to the notice and inventory requirements of s 133 , as well as the procedural requirements in subpart 6 above. ${ }^{66}$

Taking a forensic copy may be necessary for two reasons: ${ }^{67}$

1. To apply forensic investigative techniques in order to identify the evidential material, which it is generally not practicable to do onsite.

2. To preserve the evidential integrity of the material, which would otherwise be contaminated by the copying of fragments of data from the hard drive.

There is one provision in s 161 (in subpart 6) that gives specific direction as to the disposal of forensic copies. A forensic copy that contains only non-evidential material has to be destroyed under s 161(1). S 161(2) is the most useful provision whereby if the copy contains a mixture of data that is evidential and non-evidential, the forensic copy "can" be retained in its entirety and continue to be searched.

66 Warren Young, Neville Trendle and Richard Mahoney Search and Surveillance Act and Analysis (Brookers, Wellington, 2012) at [SS3.46.01].

67 At [SS110.13]. 
The Law Commission recommended this be enacted for practical reasons to preserve the evidential integrity of the copy and save time that is likely to be needed to separate out irrelevant material. ${ }^{68}$ A public policy argument favoured weighing the expediency of retaining the whole copy for the purposes of prevention and detection of crime over the privacy rights of the individual.

\section{Position under MACMA}

(a) Are forensic copies subject to the Attorney-General's direction?

Winkelmann $\mathrm{J}$ in Dotcom recognised that the wording of s 49 does not address how copies fit within the regime. ${ }^{69}$ However, held that this did not need to be addressed because the Attorney-General did give a direction that any items seized were to remain in the custody and control of the Commissioner of Police. "70 "Custody" was given a broad meaning to include forensic copies as they were under the control of the police; therefore sending the forensic copies was found unlawful. ${ }^{71}$ This would have been a correct interpretation of s 49 given that the Search and Surveillance Act was not enacted until after the dispute in Dotcom.

The position now would be that forensic copies are not subject to the AttorneyGeneral's direction because s 49 refers to "things seized". This can create undesirable consequences for the individual's privacy rights as copies can be sent without any direction from the Attorney-General, and also creates uncertainties for the police on how to handle copies made. This would undermine the purpose of s 49 to ensure all items relevant to the criminal matter remain under the Attorney-General's control. Leaving a position where the wording and purpose of MACMA conflicts with the Search and Surveillance Act, illustrating the difficulty caused by domestic law only contemplating police custody of items. Winkelmann J's approach to give "custody" a wide meaning to include all items under police control can ensure that forensic copies remain under the

\footnotetext{
68 Search and Surveillance Powers, above n 39, at [13.72].

69 Dotcom, above n 1, at [94].

70 At [95].

71 At [94].
} 
Attorney-General's direction, alternatively this can be imposed as a search warrant condition.

\section{(b) What about mixed content devices?}

The position of a 'mixed content device' is open under MACMA as to whether a forensic copy be retained in its entirety or whether irrelevant material has to be deleted. The pre-Search and Surveillance Act position was that the police did not have a right to retain the irrelevant material on mixed content devices. ${ }^{72}$ The current position still reflects this in part, as s 161 states it "can" be retained in its entirety.

In the second judgment, Winkelmann J used s 161 of the Search and Surveillance Act to inform her decision. The orders made show the intention that irrelevant material still has to be protected where possible. Irrelevant material ordered to be deleted was limited to personal photographs and film, recognising that further technical directions to give effect to this may be required. ${ }^{73}$ Winkelmann $\mathrm{J}$ acknowledged that it was unknown how difficult the process for the sorting would be. ${ }^{74}$ Preference should be given to the wishes of the requesting country, however, it is for the requested country to ultimately decide how best to give effect to the request. New Zealand authorities must weigh the rights involved and decide whether retaining the entirety of the copy is necessary, and whether irrelevant material can be deleted without impeding expediency.

A concern in the judgment was that once copies were sent overseas, the police had little control over them to "compel their return, nor prevent the FBI dealing with them as it chose". ${ }^{75}$ However, evidence obtained can only be used for the specific purpose it was given, this is contained in MACMA for New Zealand authorities using material obtained abroad, and there will be comparable legislation in the requesting country to protect the rights of the individual. ${ }^{76}$

\footnotetext{
72 Second Dotcom judgment, above n 37, at [59]; Search and Surveillance Act and Analysis at [SS110.13].

Ibid, second Dotcom judgment, at [59].

Ibid.

75 Dotcom, above n 1, at [96].

76 MACMA, s 23.
} 
(c) Legislative action?

Legislative amendment for MACMA is necessary to clarify the position. These are likely to be important issues as forensic copying allows for a faster process and for data to be examined later. ${ }^{77}$ It is encouraged where the original device is not required, and in the current technological era more information is likely to be contained on computer hard drives rather than hard copy documents. If it is not clear for New Zealand authorities how to deal with forensic copies under MACMA, it will also be difficult for the requesting country to frame a valid and specific request. If the police can retain mixed content devices in their entirety under a domestic warrant, they need to know how to deal with them under a MACMA request.

Inserting a provision in s 49, similar to that of s 161, would bring MACMA into line with domestic law and ensure that mixed content devices do not slip into a legislative gap. It might only be clear after execution the extent of irrelevant material, s 161 recognises that expediency for authorities may be more important. In practice, however, courts have favoured separation of irrelevant material. Cooperation should recognise a compromise that reflects the scope of the request and mitigates against erosion of the rights of the individual where possible. In the interim, as will be discussed in the next Section, the Attorney-General can impose conditions to subject forensic copies to its custody and control.

\section{$V$ Imposition of Search Warrant Conditions}

The most important tool the requested country has to achieve domestic compliance is imposing conditions on the search warrant. The imposition of conditions can take account of any factors that would be likely to exacerbate the intrusiveness of the execution of a warrant and ensure that the search and seizure is in conformity with domestic law requirements. $^{78}$ The main danger with this approach is that imports too much flexibility and uncertainty into the process. However, requiring mandatory conditions constrain the

77 Search and Surveillance Powers, above n 39, at [7.36].

78 At [4.145]. 
fact-specific nature of requests. The major advantage of imposing conditions is that it can cope with developments in crime and technology, rather than requiring legislative change.

Under s 29 of MACMA, the Attorney-General has the power to impose any conditions it thinks fit. This is also consistent with s 5 of MACMA which allows new forms of formal and informal cooperation to develop. Similar provisions for the imposition of conditions are contained in the equivalent Australian and Canadian legislation, as well as the United Nations Model Treaty and Harare Scheme. ${ }^{79}$

Winkelmann $\mathbf{J}$ explores this option of imposing conditions under s 45(3) of MACMA. Although this provision has been repealed since Dotcom, the same provision is now contained in s 103(3)(b) of the Search and Surveillance Act for the constable and issuing judge. S 103(3)(b) envisaged imposing conditions such as the time of execution and writing a search warrant report, however this does not mean it cannot be used for this purpose under MACMA. ${ }^{80}$ These conditions will be contained on the search warrant document for the individual and executing authorities to know the parameters of the execution.

\section{A Joint Investigative Teams}

Winkelmann $\mathrm{J}$ in Dotcom highlighted the difficulty for the police in ascertaining relevancy of the seized items as they did not have the same level of knowledge as the requesting country's authorities. Joint investigative teams can be used to overcome this operational information barrier and ensure a more expeditious process. MACMA is open to new developments to enhance cooperation. It is permissible under both ss 5 and 29 for joint investigation teams to develop as a form of cooperation and as a condition to be imposed on the execution of the request.

79 Mutual Assistance in Criminal Matters Act 1987 (Cth); Mutual Legal Assistance in Criminal Matters Act RSC 1985 c 30; United Nations Model Treaty on Mutual Assistance in Criminal Matters 1990, art 4(4); Harare Scheme, art 23(1)(b) and art 32.

80 Search and Surveillance Powers, above n 39, at [4.143]. 
Imposition of this condition depends on the context. Winkelmann $\mathbf{J}$ was adamant that the FBI should have helped with the execution of request and subsequent sorting: ${ }^{81}$

To enable the MACMA regime to achieve its purposes, it seems inevitable that in complex cases the investigating authorities must be engaged in the sorting exercise, which proper execution of the warrant requires.

This can overcome the problems for how and who is to do the sorting process, as identified earlier. Canadian courts have been sceptical about extent of the involvement of requesting country's authorities in execution of the request; viewing it as susceptible to 'capture' by the requesting country. ${ }^{82}$ Article 13 of the Convention on Mutual Assistance in Criminal Matters between the Member States of the European Union sets out a framework for the composition and operation of these teams to ensure that this concern does not eventuate. ${ }^{83}$ Furthermore, the restriction on the use of evidence provides an important safeguard for the individual and it can prevent foreign officers from using information obtained for any other purpose other than the specific offence.

Joint investigative teams are easier to set up and manage in the European Union because of political, economic and physical connectedness. A joint investigative team was used in $R v$ Secretary of State for the Home Department and Others Ex Parte Fininvest S.p.A and Others, where the Italian authorities accompanied the British in executing the search warrant request in England, mainly because the documents were in Italian. ${ }^{84}$ They will not always be necessary, as detailed sharing of information and cooperation (both formal and informal communication) can be sufficient for the requested countries to carry out the sorting process themselves. The Mutual Legal Assistance guidelines in the United Kingdom allow a requesting country to justify why their personnel should accompany the

81 Dotcom, above n 1, at [85].

82 Germany (Federal Republic) v Ebke 2001 NWTSC 52, (2001) 158 CCC (3d) 253 (NWTSC) at [90];

Robert J. Currie "Search Warrants Under the Mutual Legal Assistance in Criminal Matters Act" (2003)

12 C.R. (6th) at 275 at 280-281. It is viewed as defeating the purpose of the 'sending hearing' where the court determines whether foreign officials should have access to evidence seized.

83 Convention on Mutual Assistance in Criminal Matters between the Member States of the European Union [2000] OJ C 197/01), art 13.

${ }^{84} R v$ Secretary of State for the Home Department and Others Ex Parte Fininvest S.p.A and Others [1997] 1 WLR 743 (Div Ct). 
execution of the search warrant. ${ }^{85} \mathrm{New}$ Zealand too should be open to this, and identify it as a tool to be used for expediency.

\section{B Offsite Sorting for Electronic Material}

In Dotcom, the police did some sorting onsite, but evidence was that they had only limited information available to them to assist with this task. ${ }^{86}$ Winkelmann $\mathrm{J}$ held that even if the warrant was specific as to offence and items to be seized: ${ }^{87}$

...It may have been appropriate to impose conditions because those conditions could have addressed just how the offsite sorting exercise was to be undertaken. In considering whether to impose conditions it was relevant for the Judge in this case to weigh the inevitability of an offsite sorting exercise, the likely size of that exercise, and the requirements for cloning the content of the digital storage devices.

In searching a person's computer the concern is that a large amount of information of many different types, unrelated to the basis for the search, is potentially accessible. ${ }^{88}$ Seized items should be ascertained for relevance in the requested country so that they remain subject to the direction and jurisdiction of the requested country's courts. Once sent overseas, the requested country relies on the voluntary return of materials.

Conditions should address the factors such as whether an original or copy of the hard drive is required, and where and when it will take place. This will depend on the type and amount of items to be searched. Both of these methods will require making a forensic copy of the computer hard drive. Even though in Dotcom the police said that forensic copies would not suffice because the originals contain encrypted data, Winkelmann J ordered that all of these hard drives be copied any way. ${ }^{89}$ This demonstrates the inclination to make

85 United Kingdom Home Office Requests for Mutual Legal Assistance in Criminal Matters: Guidelines for authorities outside of the United Kingdom $\left(10^{\text {th }}\right.$ ed, London, 2012) at 32.

86 Second Dotcom judgment, above n 37, footnote 22.

87 Dotcom, above n 1, at [81].

88 Search and Surveillance Powers, above n 39, at [7.14].

89 Second Dotcom judgment, above n 37, at [55] and footnote 23. 
forensic copies where possible, and although in subpart 6, it is also contained in s 152 of the Search and Surveillance Act.

1 Would the appointment of an independent supervising solicitor help in the execution and sorting exercise?

Following the failure of domestic authorities to form a process to ascertain relevance, Winkelmann $\mathrm{J}$ in Dotcom set out a process, as a form of discretionary relief, for an independent barrister/solicitor to conduct a review of all of the items seized for relevancy. The second judgment ordered the process to be completed at police expense.

Appointing an independent practitioner is similar to the process for a search order in the civil jurisdiction (previously known as an Anton Piller order) used to secure or preserve evidence. An independent practitioner accompanies the party carrying out the search to supervise its execution as such searches are between private parties, and whatever else the court thinks fit under the order. ${ }^{90}$ A search order is different to a search warrant because it is dependent on the defendant's consent, whereas a search warrant is a key law enforcement role. ${ }^{91}$

The key argument for an independent practitioner is to safeguard the rights of the defendant and ensure the process is fair. ${ }^{92}$ The main challenge under MACMA is ensuring that the requested country knows how to ascertain relevance. An independent practitioner is unlikely to be able to help with this, as effective cooperation is the solution to the operational knowledge barrier. To allow an independent practitioner to take on this role would substitute a key aspect of a law enforcement role. There is no requirement for independent supervision under domestic law, and it could slow down the process and increase costs.

A different argument could be made if there are privilege issues involved. In the United Kingdom, the courts have encouraged officers to involve independent counsel in domestic

90 High Court Rules, r 33.7.

91 Search and Surveillance Powers, above n 39, at [12.82].

92 John Katz Search Orders, (LexisNexis, Wellington, 2011) at [6.1]. 
searches to review claims of privilege on the premises. ${ }^{93}$ The Law Commission only considered the appointment of an independent practitioner for searches of confidential client material held at lawyer's premises, and decided it should be considered on a caseby-case basis as a warrant condition. ${ }^{94}$

Existing measures can adequately safeguard the individual as police are presumed to act in accordance with domestic law, and their actions can be challenged in a judicial review proceeding by the individual. Under the Search and Surveillance Act enforcement officers are also able to take photographs, record images and sound to protect themselves from allegations of impropriety in accessing the place to be searched or in undertaking the search. $^{95}$

\section{$C$ Retention of Mixed Content Devices}

As outlined earlier, s 161 of the Search and Surveillance Act does not apply to MACMA. Forensic copies can be dealt with entirely at the option of New Zealand authorities. The main concern is the irrelevant material on these copies and whether it is to be deleted. This exercise may appear to be retrospective, as it is likely that the extent of this will only be uncovered once forensic copies are searched. If there is a substantial amount of material, the use of joint investigative teams could ensure an expedient process to delete irrelevant material.

S 29 of MACMA can be used to ensure that forensic copies remain subject to the direction of the Attorney-General, and that they remain in police custody pending this. However, the ambiguity as to whether forensic copies are subject to the AttorneyGeneral's direction may not be so important with countries like the United Kingdom trending towards sending material seized straight to the foreign authority instead of through the Central Authority. The concern rather should be focused on the material in these copies.

93 Search and Surveillance Powers, above n 39, at [12.51].

94 At [12.13].

95 Search and Surveillance Act 2012, ss 110 (i) and 162. 
Winkelmann $\mathbf{J}$ said that Dotcom did not point to any particular private digital material contained on the devices, and presumed that the concern was over personal photographs and film. ${ }^{96}$ The procedures in place for when legally privileged material may be copied could be used for irrelevant material. S 147 of the Search and Surveillance Act allows that any person who wishes to claim privilege must provide a particularised list of things in respect of which the privilege is claimed, if that is not possible they can apply to a judge for direction. Domestic authorities would then have to put in measures to exclude this material. Privilege guarantees the right of an individual to independent legal advice. It is an important guarantee of the rule of law, and therefore considerations to completely exclude other irrelevant material from a forensic copy are not as important as protecting privilege. However, this process can be useful for determining what and whether irrelevant material is to be deleted, with the judge weighing the individual's rights against the importance of evidential integrity, and the prevention and detection of crime.

\section{Provision of copies}

Dotcom ordered that the individual must be provided with an entire copy of the hard drive before a "disclosable" copy (one where irrelevant material is deleted) is sent overseas. There is no statutory authority for this approach as it was a discretionary relief outcome in a judicial review proceeding. This can be a useful condition to impose if electronic material will be seized in the search warrant and police retain the hard drive for the duration of the request. Conditions can be effective in incorporating a common-sense, creative problem-solving approach to search warrants. These provisions should be utilised more for New Zealand to be responsive to MACMA requests.

\section{Conclusion}

Dotcom v Attorney-General provides a platform for discussion on implementing a MACMA request. The statutory provisions are deliberately flexible to enable authorities to ensure that a request can be carried out in accordance with domestic law whilst also enabling its purpose to operate. The Attorney-General plays a central role in accepting and

\footnotetext{
96 Second Dotcom judgment, above n 37, at [59].
} 
carrying out a request. The Attorney-General ensures that the request contains only lawful steps and where it goes outside this, cooperation with the requesting country should cut back this step. This article concluded that the mandatory refusal provision in s 27(1)(h) of MACMA should only be utilised if the request cannot be read down to accord with domestic law.

The form and content of search warrants, and procedures for seized items has been superseded by the Search and Surveillance Act 2012, enacted after Dotcom. This leaves the enduring problem that this domestic legislation does not contemplate foreign investigation and proceedings. The areas where the interaction between the two statutes leaves uncertainties are in the direction for seized items particularly forensic copies, and whether irrelevant material must be deleted from them. S 49 of MACMA can be given a broad interpretation to include forensic copies, as this provision is intended to ensure that all items relevant to the criminal matter be under the Attorney-General's direction. The courts have upheld the tradition to delete irrelevant material on forensic copies where possible, and this should be considered a condition to impose on the warrant if legislative amendment does not occur. Cooperation must also overcome uncertainties relating to determining the level of specificity in the warrant application and relevance of material to the offence. These can be propounded by the lack of operational knowledge for domestic authorities.

New Zealand can provide the widest measure of cooperation available using the provisions in MACMA, but this power should also protect the rights of the individual. MACMA is sufficiently flexible to deal with changing circumstances and can fill in the gaps where the application of domestic legislation is uncertain. The imposition of search warrant conditions can respond to the number of exigencies that a request entails and will be useful for the requested country to ensure a lawful execution. The conditions that can be imposed include using joint investigative teams to help ascertain relevance; creating procedures for the offsite sorting process; and providing guidelines for managing mixed content devices by weighing the rights of the individual against the interests of preventing and detecting crime.

Ultimately, search warrant requests will be unique to the particular offence and details. The role of the requested country is to be alert to the number of possibilities and 
implications for the warrant execution, and use the flexibility of MACMA provisions to enable this execution in accordance with domestic law. The success of MACMA in addressing transnational crimes lies in the effectiveness of cooperation between authorities to ensure that circumstantial factors are translated into the warrant application and execution. 


\section{Bibliography}

A Cases

1 New Zealand

A (Firm of Solicitors) v District Court at Auckland [2012] NZCA 246, [2012] 2 NZLR 844.

A v District Court at Auckland CIV-2011-404-4796 22 December 2011.

Bujak v Solicitor-General [2009] NZSC 42, [2009] 3 NZLR 179.

Solicitor-General v Bujak [2008] NZCA 334, [2009] 1 NZLR 185.

Civil Aviation Authority of New Zealand v Heavylift Cargo Airlines Pty Ltd [2008] NZCA 76, [2008] 2 NZLR 391.

Dotcom v Attorney-General [2012] NZHC 1494, [2012] 3 NZLR 115.

Dotcom v Attorney-General [2013] NZHC 1269.

$R$ v Connolly (No 1) [2004] 3 NZLR 794.

Smith Re [1999] 14 CRNZ 391.

Solicitor-General v Beneficial Owners of Various Bank Accounts CIV-2008-485-1070, 21 May 2008.

Webb Ross Johnson v District Court at Whangarei HC Whangarei CP1/99, 5 February 1999.

2 United Kingdom

Crown Prosecution Services v Gohil [2012] EWCA Civ 1550, [2013] 2 WLR 1123.

Director of the Serious Fraud Office v A [2007] EWCA Crim 1927.

Government of the United States of America v Montgomery (No 2) [2004] UKHL 37, [2004] 1 WLR 2241. 
Hafner v Secretary of State for the Home Department [2006] EWHC 1259 (Admin), [2007] 1 WLR 950.

Ismail v Secretary of State for the Home Department [2013] EWHC 663 (Admin).

JP Morgan Chase Bank National Association v The Director of the Serious Fraud Office [2012] EWHC 1674 (Admin).

King v Director of the Serious Fraud Office [2009] UKHL 17, [2009] 1 WLR 718.

Liangsiriprasert v United States Government [1991] 1 AC 225 (PC).

$R$ (Abacha) $v$ Secretary of State for the Home Department [2001] EWHC 787 (Admin).

$R$ (Energy Financing Team Ltd) v Bow Street Magistrates' Court [2005] EWHC 1626 (Admin), [2006] 1 WLR 1316.

$R v$ Secretary of State for the Home Department and Others Ex Parte Fininvest S.p.A and Others [1997] 1 WLR 743 (Div Ct).

\section{Australia}

Director of Public Prosecution v Peniche [2000] VSCA 40.

4 Canada

Germany (Federal Republic) v Ebke 2001 NWTSC 52, (2001) 158 CCC (3d) 253 (NWTSC).

$R v$ Budd (2000) 150 CCC (3d) 108 (ONCA).

$R v$ Gladwin (1997) 116 CCC (3d) 471 (ONCA).

B Legislation, Treaties and Conventions

1 New Zealand

Criminal Proceeds (Recovery) Act 2009. 
Evidence Act 2006.

High Court Rules.

Mutual Assistance in Criminal Matters Act 1992.

New Zealand Bill of Rights Act 1990

Search and Surveillance Act 2012.

\section{International}

Convention on Mutual Assistance in Criminal Matters between the Member States of the European Union [2000] OJ C 197/01.

Crime (International Co-operation) Act 2003 (UK).

Model Treaty on Mutual Assistance in Criminal Matters GA Res 45/117, A/Res 45/117 (1990).

Mutual Assistance in Criminal Matters 1987 (Cth).

Mutual Legal Assistance in Criminal Matters Act RSC 1985 c 30.

Scheme Relating to Mutual Assistance in Criminal Matters within the Commonwealth (Harare Scheme).

\section{Government Materials and Other Reports}

1 New Zealand

Crown Law Office "Assistance for Foreign Authorities: Central Authorities" <www.crownlaw.govt.nz/pagepub/docs/afa/centralauthorities.asp\#7>

Law Commission 'Search and Surveillance Powers' (NZLC R97, 2007).

(20 August 1992) 528 NZPD 10826.

2 International 
Law Reform Committee, Parliament of Victoria Warrant Powers and Procedures (2005).

Report of the Informal Expert Working Group on Mutual Legal Assistance Casework Best Practice (United Nations Office on Drugs and Crime, Vienna) 3-7 December 2001.

Scheme Relating to Mutual Assistance in Criminal Matters within the Commonwealth: Explanatory Material prepared for Commonwealth Jurisdictions (Commonwealth Secretariat, London, 1988).

United Kingdom Home Office Requests for Mutual Legal Assistance in Criminal Matters: Guidelines for authorities outside of the United Kingdom $\left(10^{\text {th }}\right.$ ed, London, 2012).

D Texts

Bassiouni, M. Cherif (ed) International Criminal Law (3rd ed, Martinus Nijhoff Publishers, Leiden, 2008) vol 2.

Beck, Andrew Principles of Civil Procedure (3rd ed, Thomson Reuters, Wellington, 2012).

Blanchard, Peter (ed) Civil Remedies in New Zealand (2nd ed, Brookers, Wellington, 2011).

Boister, Neil An Introduction to Transnational Criminal Law (Oxford University Press, Oxford, 2012).

Collins, Lord L.A et al (eds) Dicey, Morris \& Collins on the Conflict of Laws $\left(15^{\text {th }}\right.$ ed, Sweet \& Maxwell, London, 2012).

Gee, Steven Gee on Commercial Injunctions, (5th ed, Sweet \& Maxwell, London, 2004).

Heron, Michael and La Hood, Dale "Search and Surveillance Act 2012- new powers" (paper presented to New Zealand Law Society Continuing Legal Education course, June 2012).

Katz, John Search Orders (LexisNexis, Wellington, 2011).

McClean, David International Co-Operation in Civil and Criminal Matters (3rd ed, Oxford University Press, Oxford, 2012. 
Nicholls, Clive, Montgomery, Clare and Knowles, Julian B. The Law of Extradition and Mutual Assistance (2nd ed, Oxford University Press, Oxford, 2007).

Young, Warren, Trendle, Neveille and Mahoney, Richard Search and Surveillance Act \& Analysis (Brookers, Wellington, 2012).

\section{E Journal Articles}

Currie, Robert J. "Search Warrants Under the Mutual Legal Assistance in Criminal Matters Act" (2003) 12 C.R.(6th) at 275.

Harfield, Clive "A review essay on Models of Mutual Legal Assistance: Political Perspectives on International Law Enforcement Cooperation Treaties" (2003) 27(2) Int'1 J.Comp.\& Applied Crim.Just. 221.

Heymann, Phillip B. "Two Models of National Attitudes Toward International Cooperation in Law Enforcement" (1990) 31 Harv.Int'1 L.J 99.

Kerr, Orin S. "Search and Seizures in a Digital World” (2005) 119 Harv.L.Rev. 531.

Laddie, Hugh and Dockray, Martin "Piller problems" (1990) 106 L.Q.R 601.

Mason, Stephen and George, Esther "Digital evidence and 'cloud' computing" (2011) 27 C.L.S.Rev. 525.

McClean, David "Mutual Assistance in Criminal Matters: The Commonwealth Initiative" (1988) 37(1) ICLQ177.

\section{F Internet Resources}

Fisher, David "Dotcom lawyers argue to see evidence" The New Zealand Herald (online ed, Auckland, 30 July 2013).

Hughes, Gary "Kim Dotcom and the "Mega Conspiracy"” Anti-money laundering (AML) magazine (Australia, May 2012) at 17.

McKenzie, Campbell and Armstrong, Sarah "How to catch an electronic thief" NZLawyer Online (New Zealand, 16 May 2008) at F6. 
Word count

The text of this paper (excluding cover page, abstract, table of contents, footnotes and bibliography) is 7, 999 words. 